УДК: $7.032(37)+72.04: 73$

ББК: $85.133(3)$

A43

DOI: $10.18688 /$ aa199-1-10

N. Gavrilović Vitas

\title{
Beyond the Borders: The Significance of Frontiers between Central Balkans' Roman Provinces in the Context of Roman Art ${ }^{1}$
}

After the Roman conquest of the territory of the Central Balkans, different indigenous tribes with inhabitants of Illyrian, Thracian, Dacian and Celtic origin [16, pp. 53,66], came under the administrative and military control of the Roman state. It is generally accepted that the term "Central Balkans" refers to the territory of today's eastern Bosnia, bigger part of Montenegro, Serbia and northern Macedonia, that is in the earlier Roman period the eastern part of the Roman province Dalmatia and the whole territory of Moesia Superior (from the end of the $3^{\text {rd }}$ century, parts of the provinces Dalmatia, Moesia Prima, Praevalitana, Dardania, Dacia Mediterranea and Dacia Ripensis) (Fig. 1). In the pre-Roman period, in the central and eastern parts of the Central Balkans, Dardanians and Thracian tribes of Moesi and Tribali were predominant, while in the western parts of the Central Balkans different Illyrian tribes were

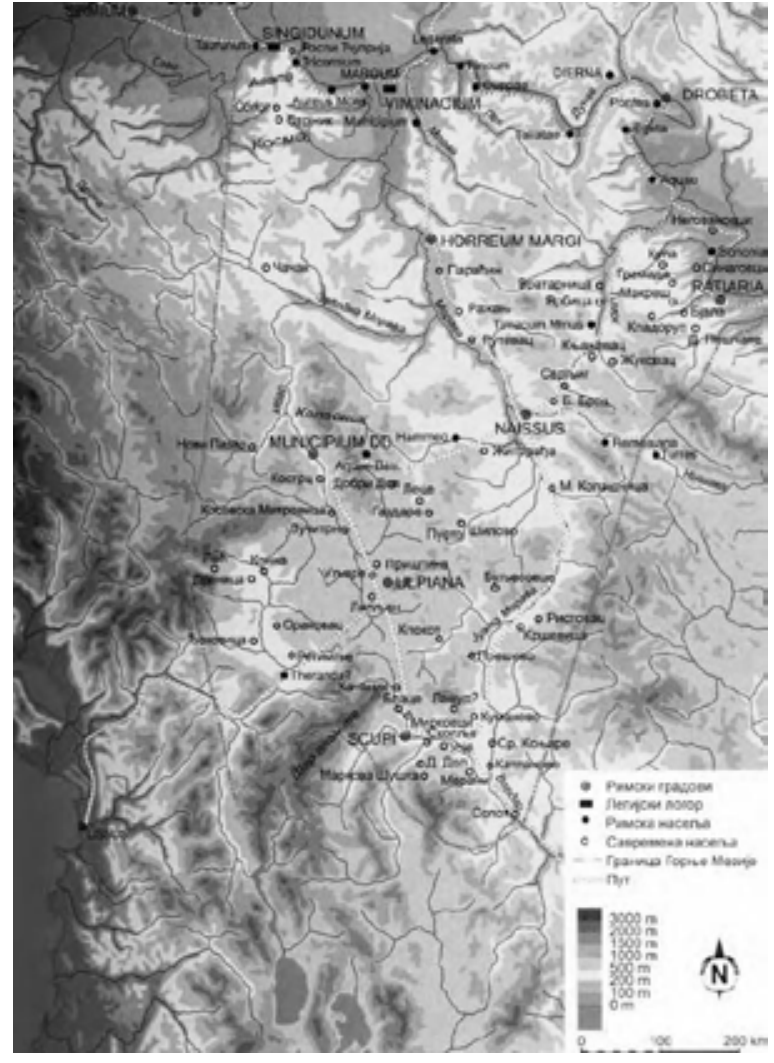

Fig 1. Map of Central Balkans territory in Roman period (Mirković M. Rimljani na Đerdapu, Zaječar 2015, p. 1)

The article results from the project: Romanization, urbanization and transformation of urban centres of civilian and military character in the Roman provinces in the territory of Serbia (no. 177007), financed by the Ministry of Education, Science and Technological Development of the Republic of Serbia. 


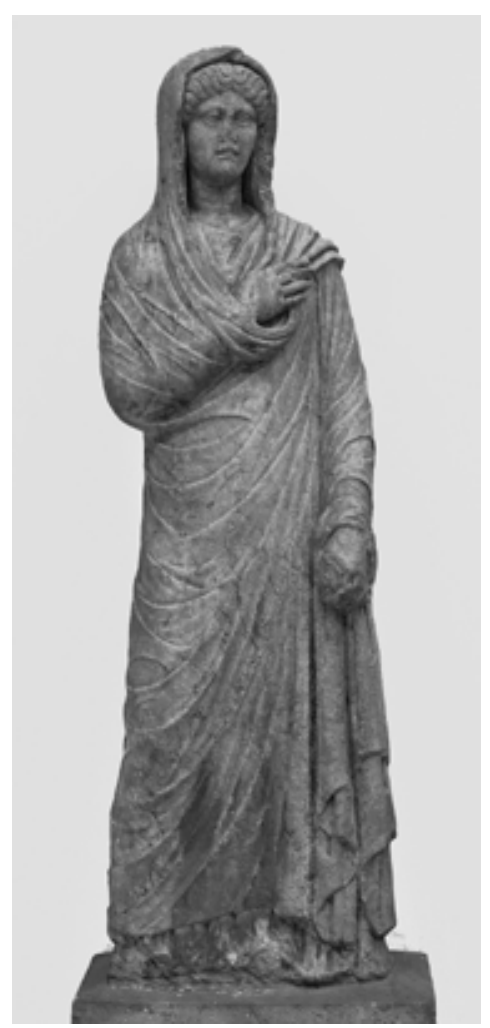

Fig. 2. Draped woman from Singidunum. Available at: http:// www.narodnimuzej.rs/antika/zbirkarimskog-carskog-perioda/C National museum Belgrade, Serbia prevailing $[16$, p. 6]. After the provinces were constituted, indigenous inhabitants were assigned to administrative units called civitates peregrinae. However, as A. Mócsy rightly points out, the territories of the civitates didn't always correspond with the size of the areas where certain tribes lived in the period before the Roman reign [16, pp. 68-69]. This had its consequences in the later diffusion of Roman culture, art and religion throughout Roman provinces of the Central Balkans.

As a natural hinterland of Greece, the region of Central Balkans came very early into the contact with Greek culture - already from the middle of the $7^{\text {th }}$ century B.C., which is visible in the material culture in the southern parts of the region, while the inhabitants of the northern parts were more under the influence of Roman conquerors and adapted more readily to the process of Romanization [9, p. 45]. Larger centres in the Central Balkans' Roman provinces, like Singidunum, Viminacium, Naissus, Scupi and military centres along the Danube limes, were the places where Roman sculptures appeared during the $1^{\text {st }}$ century, mostly due to the cultural and artistic influences from Rome through Aquileia, Salona and Sirmium [23, pp. 5-6], but also because of the already existing cultural contacts with the southern and south-eastern centres in Greece, Macedonia and Thrace. The earliest known sculptures are cult, monumental and honorary types, and mainly display already established art canons from the Flavian period. On the other hand, there are sculptures from a few localities in the interior of the region, where the local traits of indigenous cultures are noticeable: such as not so skilful modelling and characteristic details of material culture of local population. This can be observed in the examples of the statues of Neptune from Diana (Karataš) [23, pp. 54-55, fig. 18], statue of Jupiter enthroned from Niš (Naissus) [10, p. 389, n. 1, fig. 1] or the exquisite head of emperor Trajan found in Pontes (Kostol) [23, pp. 18-19, fig. 1]; all from the second half or the end of the $1^{\text {st }}$ century. They represent works of high quality and execution, displaying the realism of Roman portraiture. There is sometimes even similarity to the portraits of Roman emperors, like in the case of the bronze statue of Mercury from Tekija (Transdierna) the traits of which are comparable to Caligula [6, pp. 72-73, 119 , n. 122, fot. 99]. To this corpus, we can add, for example, the statue of Venus of unknown provenience [29, p. 39, fig. 53 a, b], of a slightly later date, probably from the first half of the $2^{\text {nd }}$ century. This statue and several others represent copies of Greek originals, but of lower quality - which could imply their manufacture in a local workshop. Therefore, the earliest sculptures and statues from the Central Balkans' Roman provinces present imports and locally made artworks, which display different artistic influences - from the copies of Greek 
statues dated to the period of Hadrian, like the head of Venus from Kostolac (Viminacium) or the head of Venus from Singidunum [23, pp. 64, 80-82, n. 23, 31], to the not so skilfully modelled sculptures made locally, which can be seen in the examples of the head of Diana from Kladovo $^{2}$ and fragmented marble sculpture of god Hermes (perhaps Apollo [6, pp. 113-114, n. 101, fot. 79]).

Through the whole $2^{\text {nd }}$ century, the sculptures from the major localities in the interior of Central Balkans' provinces mainly stayed under the influence of Roman art canons: from the portraits and monumental sculptures of respectable Roman men and women (honorific statues) like the ones from Singidunum or Viminacium [23, pp. 160-163, n. 70-71] (Fig. 2), to the cult sculptures like marble heads of Janus and Hecate from Smederevo [25, pp. 457-461, 469-473, n. 1, 5], or numerous marble statues of Venus from Viminacium, Singidunum or Diana (Karataš) [24, p. 87, fig. 24.4, 24.1-2, 23.3]. They all display a classicistic style of modelling, stylistically close to the Hellenistic sculptures, with noticeable artistic influences from the centres of Italy and Pannonia Inferior, which can be seen in the sculpture of Herakles with Telesphoros. These analogies (particularly in modelling of the details like hair, dress, attributes) can be demonstrated with the sculptures from Sirmium and its vicinity: for example, the head of Venus or the statue of Victoria found in Sirmium [20, pp. 82-83, 89-90, n. 10, 17].

As the capital of Roman province Moesia Superior, Viminacium represented the biggest and the most urbanized centre in the Central Balkans' area. It was an important military stronghold, where different cultural and artistic influences blended, mostly due to the mixing of the inhabitants of various origin and background. During the pre-Roman times, a tribe of Scordisci (consisting of mixed population of Celts and Illyrians) inhabited the territory of Roman Viminacium, and from the $1^{\text {st }}$ century, Dacians are also present in the aforementioned centre, which is confirmed by epigraphic monuments, archaeological finds, burial customs, gravegoods etc. [22, pp. 17-23]. During the reign of Hadrian, Viminacium becomes a municipium and was considered the most prosperous political and economic centre in Moesia Superior. As such, it advances to the status of a colony under Gordian III in 239 A.D. Already during the Severan epoch, Viminacium develops to be an important sculptors' centre, in which highly skilled foreign craftsmen from Eastern centres with the emphasized traditions of Greek sculptural heritage, were most numerous. The best examples of Roman art in that period can be observed in the head of a young woman from the locality Petka near Kostolac (Viminacium), on which the spiritual state of the portrayed woman is accentuated, with characteristic coiffure divided into webs, similarly to the portrait of the empress Plautilla from Solin (Salona), dated to the beginning of the $3^{\text {rd }}$ century $[23, \mathrm{pp} .32-33$, fig. $8 ; 10, \mathrm{p}$. 74]. The high quality of modelling can be seen also in votive and funerary monuments: in the relief of Alcestis with Hercules from the funerary stela, found as a spolia in one of the towers of the Smederevo Fortress (originally from Viminacium: [7, p. 94, n. 18]). However, like in Singidunum and other large centres in the $2^{\text {nd }}$ and $3^{\text {rd }}$ centuries, the majority of sculptures and statues from Viminacium present solid or mediocre works of art from local workshops: for example the sarcophagus of Aurelia Theodota and Aurelius Gallicus, with Psyche and Amor in the left niche and deceased couple in the right

2 Available at: http://virtuelnimuzejdunava.rs/home/the-head-of-the-roman-goddess-diana.i-89.208. html (accessed 25 September 2018). 

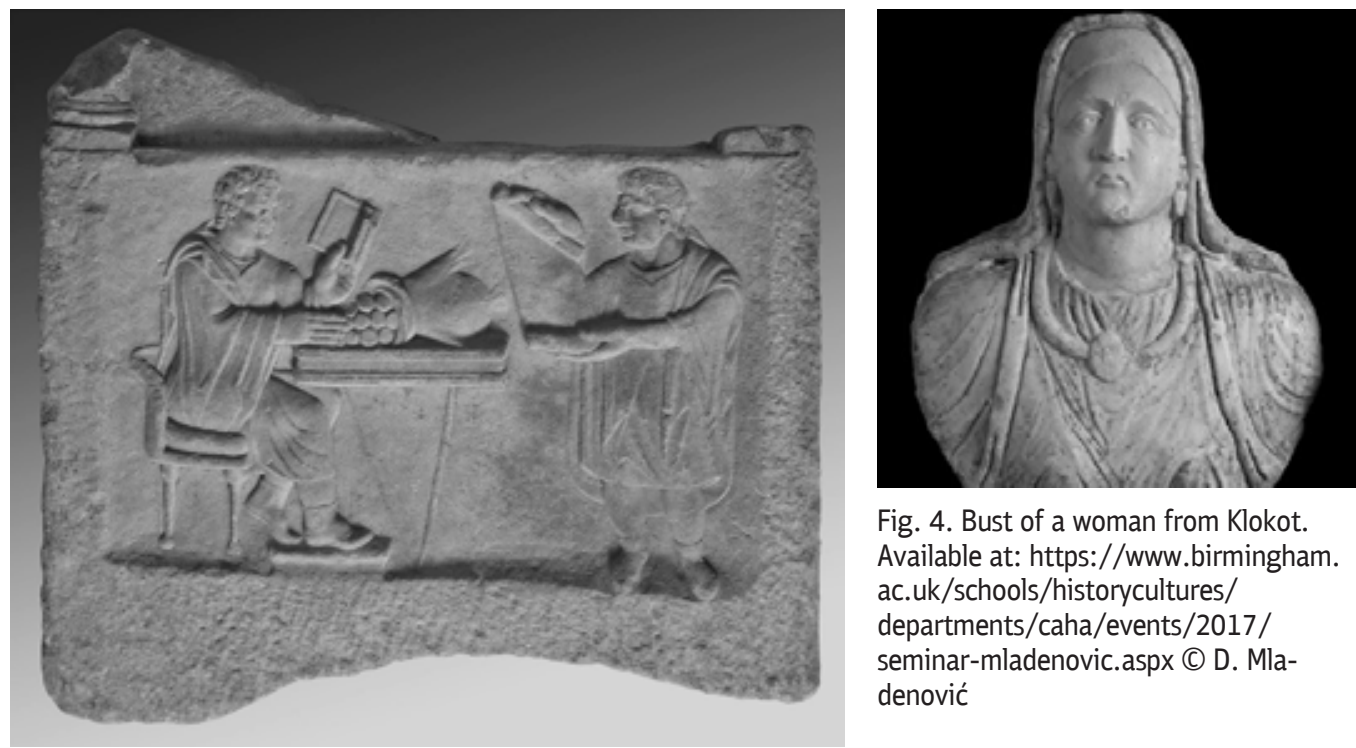

Fig. 4. Bust of a woman from Klokot. Available at: https://www.birmingham. ac.uk/schools/historycultures/ departments/caha/events/2017/ seminar-mladenovic.aspx (C) D. Mladenović

Fig. 3. Relief of a banker from Viminacium. Available at http://www. narodnimuzej.rs/antika/zbirka-rimskog-carskog-perioda/ (C) National museum Belgrade, Serbia

niche, from the $2^{\text {nd }}$ century [12, pp. $158-159$, n. $163 ; 19$, pp. 132-133, n. 6; 18, pp. 68-71] or the relief on the stela of a banker from the $3^{\text {rd }}$ century (Fig. 3). In Viminacium and a few other localities of Central Balkans' Roman provinces, funerary monuments with the images of genii of death with pedum and Attis tristis with pedum have been discovered, which are very similar to the images present on the numerous funerary monuments from eastern and south-eastern parts of the Roman province Dalmatia [6, pp. 111-127]. The monuments from Viminacium thus confirm strong artistic influence from the eastern parts of Dalmatia province, which was transferred from the coastal localities of Dalmatia to the interior of the province and then further to the major centres of Moesia Superior during the $2^{\text {nd }}$ and the $3^{\text {rd }}$ centuries. Onomastically too, migrants from mentioned parts of Dalmatia are confirmed in Viminacium and other localities of Central Balkans' Roman provinces [13].

From the end of the $2^{\text {nd }}$ century, sculptures and statues of provincial art begin to appear. In the marble bust of a woman from the locality Klokot, Gnjilane, a Roman manner of modelling can be observed, yet the dress and adornment (jewellery, massive necklace with a medallion and grape vine earrings) belong to the local tradition [3, p. 192] (Fig. 4). The flat facial expression of the woman represents the unsuccessful attempt of the sculptor to express the third dimension, but nevertheless the artist succeeded in preserving and displaying elements of autochthonous Dardanian culture in the image. The sculpture is dated probably to the second half of the $2^{\text {nd }}$ century [30, p. 149]. The emphasis on local cultural traits is also seen in the representations from funerary stelae from Peć and two reliefs from the vicinity of Peć and the vicinity of Priština [24, pp. 45-46]. The similar artistic modelling, the simplicity, two-dimensional representation and schematization can be perceived in two marble statues of women of the type Pudicitia, dated to the $3^{\text {rd }}$ century, coming from the locality Prahovo (Aquae) [24, pp. 164-166, fig. 72, 73]. 
Particular influence of indigenous cultures on the sculptural and statuary works and compositions of the $2^{\text {nd }}$ and the $3^{\text {rd }}$ centuries can be observed on finds from the south-western parts of Central Balkans' Roman provinces, for example from the localities Kolovrat [1, pp. 227-231] and Komini (known also as Municipium S). The sculptures and reliefs from these sites bear striking iconographical similarities to the works of art from the surroundings of Salona in the coastal region of the province Dalmatia. Systematic archaeological excavations combined with the analysis of onomastics and material culture [14, pp. 227-234], showed that the iconographical and stylistic parallels between the sculptures and

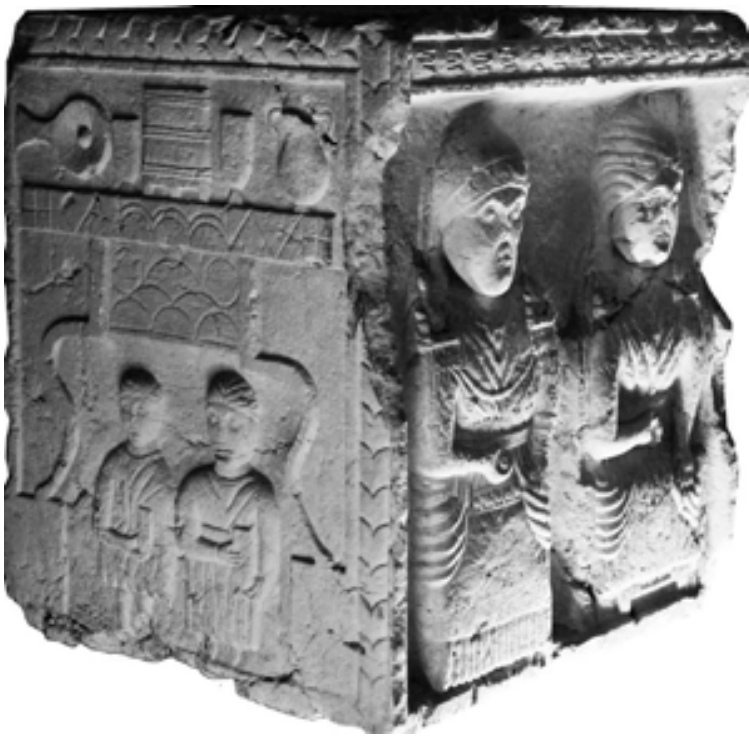

Fig. 5. Funerary monument from Seca Reka. Available at: http://lupa.at/29880/photos/1 (C project Lupa, Austria statues of two distant areas are the consequence of a resettlement of one part of Delmatae population from the rural areas near Salona to the western and south-western parts of the Central Balkans' provinces [11, p. 125]. This took place because of the Roman intention to populate these interior parts with working force for the exploitation of quarries and mines, but also because of the agricultural and economic progress which Romans intended to achieve in the area [4, p. 255; 15]. In time, resettled Delmatae assimilated indigenous population (mixed with a strong Celtic component) and this syncretism resulted in a particular artistic production with underlined conservatism, linearism and details from local material culture (like parts of the dress, adornment, various attributes like vessels, scrolls etc.). This was preserved until the end of Roman reign in the $4^{\text {th }}$ century [12], as confirmed by funerary monuments. Take, for example, the monument from the locality "Lučića groblje (Brutule)" in Seča Reka (Fig. 5) where two women are presented on the front side, wearing anchor-like fibulae with ivy leaf shaped pendants. These are part of indigenous material culture of the localities in south-western parts of Central Balkans' Roman provinces. Another example is the funerary monument of Paconia Montana from the locality Komini (Municipium S). Here, the deceased woman is presented standing in a long dress with two flowers in her right hand and a key in her left, in a familiar schematic way, yet with particular attention to the details, like the woman's dress and attributes in her hands which are characteristic of the local tradition and symbolism [2, pp. 5-7; 31, pp. 63-65].

Throughout the whole $3^{\text {rd }}$ century, we find the most interesting examples of fluidity of art in different localities of the Central Balkans. Art transcends administrative borders and produces blends of various artistic influences from different directions in the region. Judging by the known finds, the favoured sculptural type was the cult sculpture, which followed the artistic developments coming from Rome during the last two centuries of the Roman reign in the Cen- 


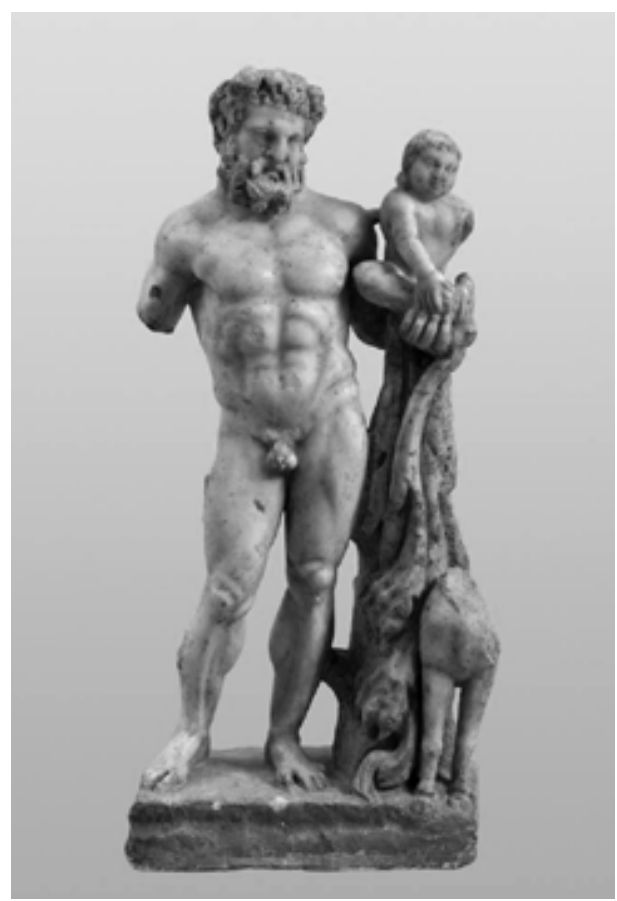

Fig. 6. Herakles with Telephos from Singidunum. Photodocumentation of the Institute of Archaeology, Belgrade (c) Institute of Archaeology Belgrade, Serbia tral Balkans' Roman provinces. Their sculptors came from big centres in Greece, Italy and Asia Minor and established workshops in Central Balkans' Roman cities, like Viminacium, Singidunum, Scupi and imperial residences like Felix Romuliana and Mediana near Naissus. But in time a certain degree of iconographic syncretism can be confirmed in their output. The sculptures, however, which were produced on the request of the local elite and were made to adorn monumental public buildings, imperial estates and private villas of rich individuals, represent the highest artistic achievements of Roman sculpture of the time, inclining to the idealization of the image and beauty of the human body. This can be perceived in the head of Heracles found in the south-eastern part of the Jupiter temple in Felix Romuliana, probably modelled after the famous statue of Heracles Farnese [7, pp. 96-97, fig. 27], the head of an emperor from Karataš on Danube Limes (perhaps Albinus?) [23, pp. 30-31, fig. 7], Jupiter enthroned, with an eagle beside his left leg from locality Kostol (Pontes) [5, pp. 48-50] and Heracles with Telephos from Singidunum [7, pp. 95-96, fig. 23] (Fig. 6). The turbulent period of the $3^{\text {rd }}$ century didn't bypass Central Balkans' area, and highlighted different art influences on sculptures and reliefs of solid and mediocre quality, found in prominent centres like Ratiaria, Viminacium, Singidunum and localities along the Danube limes region. At the same time, in the interior regions, the heritage and stylistic traits of indigenous cultures continued to influence local production of different kinds of art works. In some localities, for example, at Timacum Minus (Ravna), which was an important Roman military fortification with a civilian settlement formed nearby, certain degree of the artistic influence of Thracian culture can be perceived in cult sculptures like the marble statue of Dionysus or the head of Fortuna-Isis [17, p. 40, fig. 9; 24, pp. 102-103, fig. 42]. From the end of the $3^{\text {rd }}$ century and during the $4^{\text {th }}$ century, that is in the period of tetrarchy and particularly during the reign of the emperor Constantine the Great, the city of Naissus was prospering as a prominent political and military centre. The reign of especially Licinius and Constantine was also marked by active building projects. On the one hand, marble and bronze sculptures from Naissus show all the classicistic characteristics of Constantine's epoch: see, for example, the bronze head of the emperor, presumably from an equestrian statue which stood in the centre of the city [23, pp. 46-47, fig. 15] (Fig. 7); or the porphyry head of a tetrarch [23, pp. 42-43]. On the other hand, cult sculptures found at the imperial residence of Constantine the Great and his successors, the so-called Constantine's villa at Mediana (suburb of Naissus), represent high classical forms mixed with certain art works 

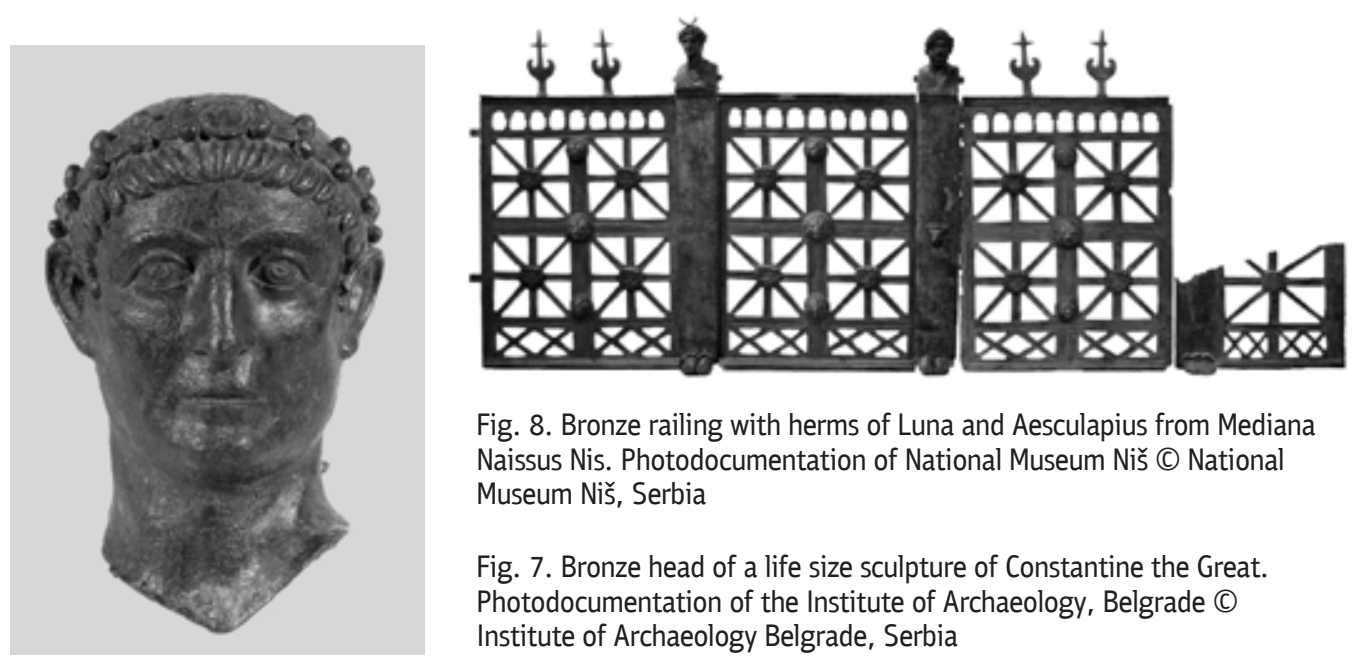

Fig. 8. Bronze railing with herms of Luna and Aesculapius from Mediana Naissus Nis. Photodocumentation of National Museum Niš (c) National Museum Niš, Serbia

Fig. 7. Bronze head of a life size sculpture of Constantine the Great. Photodocumentation of the Institute of Archaeology, Belgrade (C) Institute of Archaeology Belgrade, Serbia

with provincial traits: high quality sculptures and classically modelled heads of Asclepius with Telesphoros, Hygieia [27, pp. 92-98], Hercules, Venus, Diana, Dionysus, Satyr, Menad and sculptural compositions from the mythology of Hercules and Dionysus, were found at Constantine's villa, along with the sculpture of Dea Dardania, the indigenous goddess protectress of the Dardanian people to whom Constantius Chlorus, the father of Constantine the Great and his son, Constantine the Great, belonged. The marble sculpture of Dea Dardania was found at the entrance of the villa, emphasizing the role of the goddess as the dynastic deity and the protectress of the imperial dynasty [28, p. 94, fig. 16]. Although modelled in the classical form, the sculpture of Dea Dardania shows the clear influence of local culture in the attributes the goddess holds: a boar and a labrys in her hands represent the analogy with relief representations of Dea Dardania from Romula, capital of Dacia Malvensis [21, pp. 31-43] and confirm that in the eastern parts of Central Balkans' territory artistic influences with neighbouring provinces blended and were present until the end of the Roman reign.

New sculptural tendencies, characteristic for the period of Constantine the Great's reign in the $4^{\text {th }}$ century are particularly visible in the bronze railing with herms of Asclepius and Luna (corresponding busts of god Sol and goddess Hygieia are unfortunately missing) (Fig. 8). This exquisite and rare piece was found close to the north-western corner of the west perimeter wall (but outside of the wall) at Mediana. It probably separated the sacral space (where cult sculptures were put) in the apsidal hall of Constantine's villa from profane space [26, pp. 79-110]. As M. Vasić rightly observes, the imperial character of the bronze railing is suggested by the bust of Luna, whose portrait bears striking likeness to the face of Fausta, wife of Constantine the Great [26, p. 106]. On the other hand, the fragmented sculptural composition of a Drunken Dionysus with a Satyr found near the thermae of Constantine's villa at Mediana, shows iconographical syncretism of Dionysus and Sabazius, in the detail of a Satyr's foot on a ram's head (and not the god's foot on animal's head as it is presented in the iconography of Sabazius, who was, due to the numerous similarities with Dionysus, syncretised with him). This can be ascribed to a strong Thracian artistic and religious influence in the eastern parts of Central 
Balkans' Roman provinces [8, pp. 192-293]. However, the sculptural finds from Constantine's villa at Mediana excellently illustrate the fashion of decorating imperial estates and villas of rich aristocrats throughout the Empire in the $4^{\text {th }}$ century, when similar aesthetic ideas were spread in eastern and western provinces and pagan works of art were mostly understood by their classically educated owners as appropriate and symbolic decoration [28, pp. 100-101].

After this comprehensive review of the various artistic influences in different periods on the artistic tendencies in the Central Balkans' Roman provinces, it is clear that the northern parts with centres like Ratiaria, Singidunum and Viminacium were more Romanised and under strong cultural and artistic influence of the Roman empire. At the same time, the works of art known from the southern parts display stronger Greek influence with noticeable local traits. The western parts of the area were generally under the sway of the workshops from Aquileia and Salona until the end of the late antiquity, while the eastern parts of Central Balkans' Roman provinces incorporated elements of Thracian culture and art, recognisable in iconographic details. Artistic influences from other regions can be traced during the early Christian period as well: for example, the scene from the front side of Jona's sarcophagus from Singidunum, judging by the Noric-Pannonian volutae motive on its lateral sides, is created under the influence of Pannonian workshops, presumably the ones from Aquincum. This is confirmed by the motives of volutae represented in the sarcophagus found in Aquincum [21, pp. 147-148]. Therefore, it can be concluded that through the whole period of antiquity, on the territory of Central Balkans' Roman provinces, the administrative boundaries between the provinces established upon the arrival of Romans did not correspond to the cultural ones as well. The artistic trends and influences expressed in works of art displayed fluidity through frontiers and showed that as far as art is in question, no strict boundaries can exist.

\section{References}

1. Cermanović-Kuzmanović A. Grobnica jedne ugledne porodice u Kolovratu kod Prijepolja. Arheološki Vestnik, no. 41. Ljubljana, Research Center of the Slovenian Academy of Sciences and Arts Publ., 1990, pp. 227-234 (in Serbian).

2. Cermanović-Kuzmanović A. Komini - Municipium S....nekropole. Belgrade, Faculty of Philosophy Publ., 1998, pp. 1-23 (in Serbian).

3. Čerškov E. Antička bista žene iz Klokota. Glasnik Muzeja Kosova i Metohije, no. 3. Priština, Muzej Kosova i Metohije Publ., 1958, pp. 187-193 (in Serbian).

4. Dušanić S. Roman Mining in Illyricum: Historical Aspects. Dall' Adriatico al Danubio-L'Illirico nelletà greca e romana, Atti del convegno internazionale, Cividale del Friuli, 25-27 settembre 2003. Pisa, ETS Publ., 2004, pp. 247-270.

5. Garašanin M.; Vasić M.; Marjanović-Vujović G. Pontes-Camp et point de Trajan. Cahiers des Portes de Fer, II. Belgrade, Institut Archeologique de Belgrade; Museé National de Belgrade; Département d'archéologie de la faculté de philosophie de Belgrade; Sociéte archéologique de Serbie Publ., 1984, pp. 25-84 (in Serbian and French).

6. Gavrilović N. Kultovi maloazijskih i sirijskih božanstava u rimskim provincijama na centralnom Balkanu, Ph. D. thesis. Beograd, University of Belgrade, Faculty of Philosophy, Department of Archaeology, 2010. 370 p. Unpublished (in Serbian).

7. Gavrilović N. Kult Herkula i Merkura u Gornjoj Meziji. I-IV vek n. e. Beograd, Arheološki institut Publ., 2014. 192 p. (in Serbian).

8. Gavrilović N. The Marble Group Depicting Drunken Dionysus with Satyr from Mediana. Ante Portam Auream. Studia in Honorem Professoris Aleksandar Jovanović. Belgrade, University of Belgrade, Faculty of Philosophy Publ., 2017, pp. 193-203. 
9. Jevtović J. (ed.). Antički portret u Jugoslaviji. Narodni Muzej. Beograd, Narodni muzej Publ., 1987. 252 p. (in Serbian).

10. Korać M.; Pop-Lazić S. (eds.). Roman Limes and Cities on the Territory of Serbia. Catalogue. Belgrade, Serbian Academy of Sciences and Arts; Archaeological Institute Publ., 2018. 389 p.

11. Mandić L. Antičke nekropole jugozapadne Srbije. Užice, Narodni muzej Užice Publ., 2015. 314 p. (in Serbian).

12. Mirković M. Inscriptions de la Mésie Supérieure II: Viminacium et Margum. Belgrade, Centre deetudes épigraphiques et numismatiques Publ., 1986. 234 p. (in French).

13. Mirković M. Sirmium. Istorija rimskog grada od I do kraja VI veka. Sremska Mitrovica, Blago Sirmijuma Publ., 2008. 142 p. (in Serbian).

14. Mirković M. Municipium S. Rimski grad u Kominima kod Pljevalja. Beograd, Filozofski fakultet Univerziteta u Beogradu Publ., 2013. 159 p. (in Serbian).

15. Mócsy A. Pannonia and Upper Moesia: A History of the Middle Danube Provinces of the Roman Empire. New York, Routledge Publ., 2014. 506 p.

16. Papazoglu F. Srednjobalkanska plemena u predrimsko doba. Sarajevo, Akademija nauka i umjetnosti Bosne i Hercegovine Publ., 1969. 510 p. (in Bosnian).

17. Petković S.; Gavrilović Vitas N.; Miladinović-Radmilović N.; Ilijić B. Pogrebni ritual i Dionisov kult u Ravni. Arheološki institut, Posebna izdanja, book 57. Beograd, Knjaževac, Arheološki institut, Zavičajni muzej Knjaževac Publ., 2016. 94 p.

18. Pilipović S. Mit i ljubav. Predstave na nadgrobnim spomenicima rimske provincije Gornje Mezije. Beograd, Balkanološki institut SANU Publ., 2007. 176 p. (in Serbian).

19. Popović I. Dea Dardanica iz Medijane i srodni spomenici iz balkanskih provincija Carstva. Niš i Vizantija VI. Niš, Niški kulturni centar Publ., 2008, pp. 31-43(in Serbian).

20. Popović I. Sirmium. Mermerne Sculpture. Beograd; Sremska Mitrovica, Arheološki institute Publ., 2012, pp. 1-132 (in Serbian).

21. Popović I. "In hoc signo vinces". Konstantin Veliki i Milanski edikt. Rađanje hrišćanstva u rimskim provincijama na tlu Srbije. Katalog. Beograd, Narodni muzej Beograd Publ., 2013, pp. 138-159 (in Serbian).

22. Spasić-Đurić D. Grad Viminacijum. Požarevac, Narodni muzej Požarevac Publ., 2015, pp. 1-223 (in Serbian).

23. Srejović D.; Cermanović-Kuzmanović A. Rimska skulptura u Srbiji. Beograd, SANU Publ., 1987, pp. 1-174 (in Serbian).

24. Tomović M. Roman Sculpture in Upper Moesia. Belgrade, Institute of Archaeology Publ., 1992, pp. 1-205.

25. Tomović M.; Marković-Nikolić Lj. Marble Sculptures from the Collection of Milan Stojimirović Jovanović in the National Museum at Smederevo. Vestigatio Vetustatis. To Aleksandrina Cermanović-Kuzmanović from Friends, Colleagues and Students. Belgrade, Faculty of Philosophy Publ., 2001, pp. 453-492.

26. Vasić M. Bronze Railing from Mediana. Starinar, 2003, vol. 53-54. Belgrade, Institute of Archaeology Publ., 2004, pp. 79-110.

27. Vasić M. Sculptures and "the Sanctuary of Aesculapius" in Mediana. Starinar, vol. 68. Belgrade, Institute of Archaeology Publ., 2018, pp. 89-109.

28. Vasić M.; Milošević G.; Gavrilović Vitas N.; Crnoglavac V. Constantine’s Villa at Mediana. Niš, National Museum Niš Publ., 2016. 109 p.

29. Veličković M. Rimska sitna bronzana plastika u Narodnom muzeju. Beograd, Narodni muzej Beograd Publ., 1972. 207 p. (in Serbian).

30. Zef M. A propos de la Romanisation des Dardaniens. Iliria, no. 5. Tirana, l'Institut Archéologique d'Albanie, 1976, pp. 143-150 (in French).

31. Zotović R. Rimski nadgrobni spomenici istočnog dela provincije Dalmacije. Užice, Kadinjača Publ., 1995. 177 p. (in Serbian).

Title. Beyond the Borders: The Significance of Frontiers between Central Balkans' Roman Provinces in the Context of Roman Art.

Author. Nadežda Gavrilović Vitas - Ph. D., senior research associate. Institute or Archaeology, Knez Mihailova 35, 11000 Belgrade, Serbia.N.Gavrilovic@ai.ac.rs, nadia011@yahoo.com

Abstract. Romanisation of the Central Balkans began with the Roman conquest in the $1^{\text {st }}$ century, upon which tribal communities were organized into administrative units. The fact that the boundaries of pre-Roman tribal territories didn't correspond in total with the areas of the newly formed Roman provinces, led 
to frequent influences from neighbouring provinces and the blending of Roman art with local traits in the artistic sphere. Although in the $1^{\text {st }}$ century different types of sculpture (cult, monumental and honorary) were present, throughout the whole period of the Roman reign cult sculptures and statues were the most numerous. Tracing the development of the art in the territory of Central Balkans' Roman provinces, it is clear that the northern parts were more under the Roman influence as the consequence of indigenous population more readily adapting to the process of Romanisation, while the southern parts of the Central Balkans area were more influenced by the Greek culture with which they were in contact from as early as the middle of the $7^{\text {th }}$ century B.C. Sculptures, statues and reliefs were modelled upon Roman art canons, copying classical Greek and Hellenistic art, in bigger centres like Ratiaria, Singidunum, Viminacium, Naissus, Scupi etc. and localities along the Danube limes. At the same time, in the interior of the Central Balkans' provinces, works of art were manufactured upon Roman canons but with local traits. These were mainly recognized in the simplicity, frontality and linearity of the art works. This is particularly visible in the western and south-western parts of the aforementioned territory, as in some of the localities in eastern parts of the area. During the $2^{\text {nd }}$ and the $3^{\text {rd }}$ centuries, beside skilful artisans from Greece, Asia Minor and the Mediterranean, who came and worked in bigger centres, local workshops also produced different kinds of artworks, copying Roman types in a more or less successful way. During the $3^{\text {rd }}$ century particularly, different cultural and artistic influences met and blended, often transcending the administrative borders of the provinces, thus the forthcoming iconographic syncretism was present in the $4^{\text {th }}$ century as well. From the end of the $3^{\text {rd }}$ and during the $4^{\text {th }}$ century, rich aristocrats, local elite and emperors ordered high quality works for decorating their estates and villas, following aesthetic criteria established in other eastern and western provinces. In the art works from that period, beside certain schematism and linearity in the modelling, a blending of similar iconographic details is emphasized as the presence of local artistic traits. Therefore, the continuance of manufacturing of the sculpture by copying classical Greek works of art and of the locally produced works of art with traits of indigenous material cultures is present until the end of the Roman reign.

Keywords: Roman art; Central Balkans' Roman provinces; sculpture; indigenous cultures.

Название статьи. Переступая рубеж: значение границ между провинциями центральных Балкан для римского искусства.

Сведения об авторе. Гаврилович-Витас Надежда - Ph. D., старший научный сотрудник. Институт археологии, ул. Кнез Михайлова 35, 11000 Белград, Сербия. N.Gavrilovic@ai.ac.rs, nadia011@yahoo.com

Аннотация. С римским завоеванием в I в. н. э. начался процесс романизации центральных Балкан, в ходе которого племенные общины были объединены в административные единицы. При этом границы доримских племенных территорий не полностью совпали с вновь образованными провинциями, что обусловило взаимные культурные влияния в соседствующих провинциях, смешение римских и локальных черт в художественной сфере. В I в. наблюдается большое разнообразие скульптурных типов, однако на протяжении всего периода римского господства доминируют культовые рельефы и статуи. В искусстве на территории центральных балканских провинций заметно выраженное воздействие римской культуры - коренное население здесь достаточно легко адаптировалось к процессу романизации. Южные части центральных Балкан были в большей степени подвержены влиянию греческой культуры, с которой соприкасались еще с середины VII в. до н. э. В более крупных центрах, таких как Сингидунум, Виминациум, Наис, Скупи, статуи и рельефы изготовлялись по канонам римского искусства, с опорой на классические и эллинистические образцы. В то же время во внутренних районах центральных Балкан произведения, созданные также под влиянием римских образцов, демонстрируют выраженные местные черты, которые проявляются в упрощенности, фронтальности композиции и линейности моделировки. Это особенно заметно в западной и юго-западной частях рассматриваемых территорий, а также в некоторых населенных пунктах восточной части региона. На протяжении II-III вв. наряду с искусными приезжими мастерами из Греции, Малой Азии и Средиземноморья, работавшими в более крупных центрах, местные мастерские также производили разнообразные скульптуры, в той или иной мере успешно копируя римские типы. Так в течение III в. различные культурные и художественные влияния встречались и смешивались, зачастую пересекая пределы административных границ провинций, подготавливая почву для иконографического синкретизма IV в. Традиции изготовления скульптуры, копирующей классические образцы, сосуществовали с локальным производством с его более выраженными признаками местных художественных вкусов до конца римского правления.

Ключевые слова: римское искусство; балканские провинции Рима; римская скульптура; локальные традиции. 